\title{
AIH-FPP/ガス窒化複合表面処理による $\mathrm{S} 45 \mathrm{C}$ 鋼表面の高硬さ化
}

\author{
福岡隆弘 $1, *$ 菊池将 -2 小茂鳥 潤 3 \\ 深沢剣吾 ${ }^{4}$ 三阪佳孝 ${ }^{4}$ 川㟝一博 4 \\ 1慶應義塾大学大学院理工学研究科総合デザイン工学専攻 \\ 2 立命館大学理工学部機械工学科 \\ 3 慶應義塾大学理工学部機械工学科 \\ ${ }^{4}$ 高周波熱錬株式会社技術本部
}

J. Japan Inst. Metals, Vol. 76, No. 7 (2012), pp. 422-428

(C) 2012 The Japan Institute of Metals

\section{Increasing Surface Hardness of S45C Steel by AIH-FPP/Gaseous Nitriding Treatment}

Takahiro Fukuoka ${ }^{1, *}$, Shoichi Kikuchi², Jun Komotori ${ }^{3}$, Kengo Fukazawa ${ }^{4}$, Yoshitaka Misaka ${ }^{4}$ and Kazuhiro Kawasaki ${ }^{4}$

${ }^{1}$ School of Integrated Design Engineering, Graduate School of Science and Technology, Keio University, Yokohama 223-8522

${ }^{2}$ Department of Mechanical Engineering, College of Science and Engineering, Ritsumeikan University, Kusatsu 525-8577

${ }^{3}$ Department of Mechanical Engineering, Faculty of Science and Technology, Keio University, Yokohama 223-8522

${ }^{4}$ Technical Headquarters, Neturen Co., Ltd., Hiratsuka 254-0013

In this study, in order to increase surface hardness of S45C steel, hybrid surface modification treatment which is a combination of atmospheric-controlled induction-heating fine particle peening (AIH-FPP) and gaseous nitriding, were developed. Surface microstructures of gaseous nitrided specimens pre-treated with AIH-FPP were characterized by a scanning electron microscope (SEM), an energy dispersive X-ray spectrometer (EDX), X-ray diffraction analysis (XRD) and X-ray photoelectron spectroscopy (XPS). In the case of the AIH-FPP treated specimens with a $\mathrm{Cr}$ transferred layer, the nitrided layer was not formed. This was because diffusion of nitrogen into the surface of the specimens was disturbed by chromium oxide in the transferred layer. On the other hand, the nitrided layer was formed at the surface of the specimen with $\mathrm{Cr}$ diffused layer induced by pre-AIH-FPP, and this nitrided layer showed higher hardness than that of the specimen without AIH-FPP. However, the surface hardness decreased near the surface. In order to suppress decreasing of the surface hardness, the specimens with different $\mathrm{Cr}$ concentrations were prepared. It was clarified that the surface hardness was affected by $\mathrm{Cr}$ concentration in the $\mathrm{Cr}$ diffused layer; the lower the $\mathrm{Cr}$ concentration, the higher the surface hardness. It was assumed that the pore formation during nitriding process was inhibited by decreasing $\mathrm{Cr}$ concentration. These results suggest that surface hardness of S45C steel remarkably increases by hybrid surface treatments of AIH-FPP and gaseous nitriding.

(Received February 15, 2012; Accepted March 19, 2012; Published July 1, 2012)

Keywords: surface modification, atmospheric-controlled induction-heating fine particle peening (AIH-FPP), nitriding, surface hardness, carbon steel

\section{1. 緒 論}

表面処理の一種である窒化は, 機械部品の疲労特性や摩耗 特性の改善を目的として広く用いられている。とくに $\mathrm{Al}$, $\mathrm{Cr}, \mathrm{V}$ などの合金元素を添加したいわゆる窒化鋼の場合, 窒 化処理により高硬さの窒化物が被処理面に形成され，それに より耐摩耗性が向上することが知られている。 また近年で は, 通常の構造用鋼に対しても, クロマイジングやめっきに より表面に Cr を付与した後に窒化を施すことで, 高硬さの 窒化層を創製できることが報告1-7)されており，材料の高性

* 慶應義塾大学大学院生 (Graduate Student, Keio University)
能化を図るための新たな複合表面処理プロセスとして注目さ れている.

著者らは最近, 雾囲気制御下で高周波誘導加熱により被処 理材を高温に保持した状態で微粒子ピーニングを施すことが 可能な『雾囲気制御高周波誘導加熱微粒子ピーニング (Atmospheric-Controlled Induction-Heating Fine Particle Peening: AIH-FPP) システム』を構築 8 ) し, 材料表面に合金 元素を付与する新しい表面改質プロセスの提案を目的とした 研究を行っている.これまでに, AIH-FPP 処理システムを 用いて $900^{\circ} \mathrm{C}$ に加熱した $\mathrm{S} 45 \mathrm{C}$ 鋼に $\mathrm{Cr}$ 粒子を投射した場合 には, 投射粒子同土の衝突もしくは基材への衝突により破砕 して微細化した投射粒子の被処理面への移着に加え, 移着物 が加熱されることに起因してその成分が基材内部へ拡散する 
こと帛を明らかにしている。また，粒子投射時間，投射後の 加熱保持時間あるいは投射圧力などの処理条件を変化させる ことにより移着・拡散挙動が変化し, 被処理面に特徵の異な

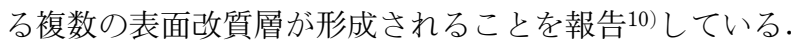

本研究は, この AIH-FPP を窒化の前処理として用いる新 しいハイブリッド表面改質プロセスを提案することを目的と して実施する。具体的には，Cr 粒子を用いた AIH-FPPを 行った後に窒化を施し，その表面に高硬さの $\mathrm{Cr}$ 窒化物を含 む改質層を形成させようとするものである. その際, 窒化層 形成メカニズムについても微視組織学的観点から検討 · 考察 を加える。

\section{2. 実 験 方 法}

\subsection{AIH-FPP 処理システム}

Fig. 1 に，著者らが構築8) した AIH-FPP 処理システムの 構成を示す。このシステムは，密閉されたチャンバー内に， 粒子噴射ノズルと高周波誘導加熱コイルが具備されており， 雾囲気を置換した状態で被処理材を加熱しながら微粒子ピー ニング処理することができる，チャンバー内の䨌囲気は，粒 子噴射ノズルを通じてガスを供給することにより置換する. IH 装置は, 加熱コイルに加えて高周波電源と出力制御装置 から構成されている．被処理材の温度は，高周波電源の出力 調整と on/off の制御により，所定の值に制御することがで きる。

\section{2 試験片の作製}

被処理材には, Table 1 に示す化学成分を有する市販の機 械構造用炭素鋼 $(\mathrm{S} 45 \mathrm{C})$ を用いた。同材を $\phi 15 \mathrm{~mm}$, 厚さ 4 $\mathrm{mm}$ の円盤型試験片に機械加工した後, 一方の端面を\# 320 〜\#1200のエメリ紙により研磨した.

この試験片を IH コイルの内側に設置した後, 粒子噴射ノ

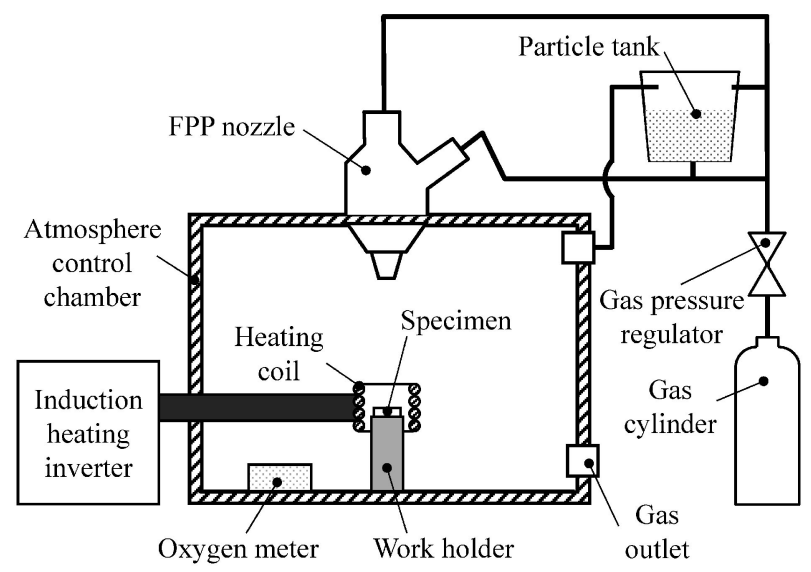

Fig. 1 Schematic illustration of atmospheric-controlled IHFPP treatment system. ${ }^{8)}$

Table 1 Chemical composition of S45C steel, $c$ (mass\%).

\begin{tabular}{llllllllllll}
\hline $\mathrm{C}$ & $\mathrm{Si}$ & $\mathrm{Mn}$ & $\mathrm{P}$ & $\mathrm{S}$ & $\mathrm{Ni}$ & $\mathrm{Cr}$ & $\mathrm{Mo}$ & $\mathrm{Cu}$ & $\mathrm{Ti}$ & $\mathrm{Al}$ & $\mathrm{Fe}$
\end{tabular}
$\begin{array}{llllllllllll}0.45 & 0.20 & 0.71 & 0.018 & 0.026 & 0.04 & 0.13 & 0.01 & 0.09 & 0.002 & 0.002 & \text { Bal. }\end{array}$
ズル (内径 $6 \mathrm{~mm}$ ) から Ar ガスを供給し, チャンバー内の䨌 囲気置換を行った。設置した酸素濃度計 (測定公差 $\pm 0.3 \%$ ) の数值が $0.0 \%$ となったことを確認した後, Fig. 2 に示す熱 サイクルで AIH-FPP を施した。 その際, 投射粒子には $\mathrm{Cr}$

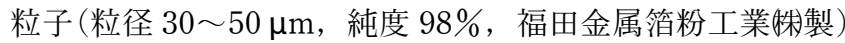
を用いた。また AIH-FPP 処理は従来の研究10)を参考にし て，(i) $\mathrm{Cr}$ 移着層のみ $(\mathrm{T}$ シリーズ), (ii) $\mathrm{Cr}$ 移着層と拡散層の

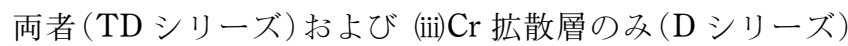
が形成される条件で行った (Table 2)。なお，シリーズ名の T, D は，それぞれ移着層 (Transferred layer)，拡散層 (Diffused layer)が被処理面に存在することを表している.

このようにして準備した試験片に対して，Fig. 3 に示す条 件のもとでガス窒化を施した。具体的には，まず窒化炉内を 真空引きした後, 流量 $200 \mathrm{~L} / \mathrm{h}$ で $\mathrm{NH}_{3}$ ガスを添加しながら $550^{\circ} \mathrm{C}$ まで昇温させた。 その後，流量 $150 \mathrm{~L} / \mathrm{h}$ で $\mathrm{N}_{2}$ ガスを 添加し， $\mathrm{N}_{2}$ ガスと $\mathrm{NH}_{3}$ ガス混合雾囲気下で 6 時間保持した 後, $\mathrm{N}_{2}$ ガスを $400 \mathrm{~L} / \mathrm{h}$ で添加した状態で炉冷した。なお，

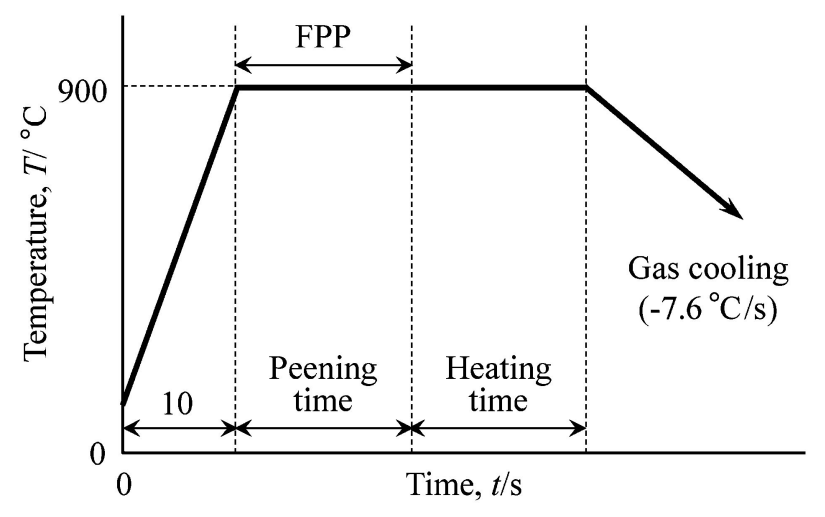

Fig. 2 Thermal condition of AIH-FPP treatment.

Table 2 AIH-FPP conditions.

\begin{tabular}{ccccc}
\hline Series & $\begin{array}{c}\text { Peening } \\
\text { pressure, } \\
p / \mathrm{MPa}\end{array}$ & $\begin{array}{c}\text { Particle } \\
\text { supply rate, } \\
\dot{m} / \mathrm{g} \mathrm{s}^{-1}\end{array}$ & $\begin{array}{c}\text { Peening } \\
\text { time, } \\
t / \mathrm{s}\end{array}$ & $\begin{array}{c}\text { Heating } \\
\text { time, } \\
t / \mathrm{s}\end{array}$ \\
\hline $\mathrm{T}$ & 0.3 & 0.2 & 30 & 0 \\
$\mathrm{TD}$ & 0.5 & 0.5 & 90 & 0 \\
$\mathrm{D}$ & 0.5 & 0.2 & 30 & 60 \\
\hline
\end{tabular}

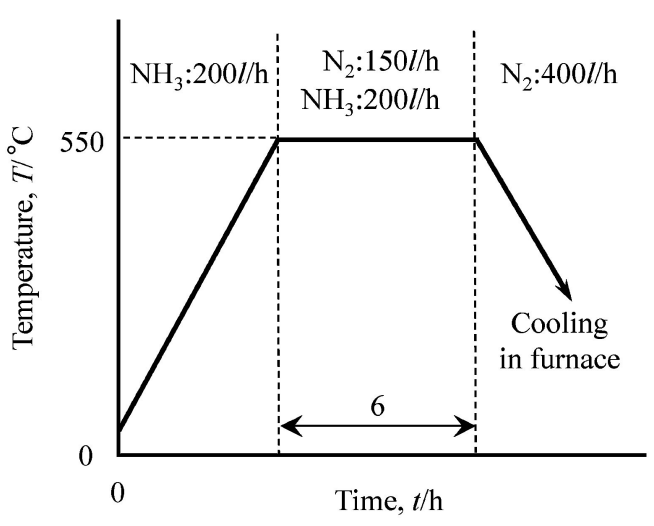

Fig. 3 Condition of Gaseous nitriding. 
ガス窒化を施した試験片は，前処理による試験片表面の状況 により， $\mathrm{T}+\mathrm{N}, \mathrm{TD}+\mathrm{N}$ および $\mathrm{D}+\mathrm{N}$ シリーズと呼ぶ。ま た，比較のために，鏡面研磨した後に窒化のみを施した試験 片 (Nシリーズ)も準備した.

\section{3 表面改質層の評価}

作製した試験片に対しては，走査型電子顕微鏡 (Scanning Electron Microscope: SEM)，エネルギー分散型 X 線分光装 置 (Energy Dispersive X-ray Spectrometer: EDX), X 線光 電子分光装置 (X-ray Photoelectron Spectroscope: XPS)，光 学顕微鏡および微小硬さ計を用いた分析を行い, AIH-FPP/ ガス窒化複合表面処理による表面改質効果について検討を加 えた。 また, 被処理面の結晶構造分析には, $\mathrm{X}$ 線回折 $(\mathrm{X}-$ ray Diffraction: XRD) 装置を用い，X 線入射角度 $10^{\circ} ， \mathrm{X}$ 線 源 $\mathrm{CuK} \alpha$ (波長 $0.154 \mathrm{~nm}$ ), 電圧 $40 \mathrm{kV}$, 電流 $40 \mathrm{~mA}, 2 \theta=$ $20^{\circ} \sim 90^{\circ}$ の条件で行った。

\section{3. 実験結果および考察}

\subsection{AIH-FPP により形成された表面改質層の特性}

本研究ではまず，従来の結果10) と同様に，Tシリーズに は $\mathrm{Cr}$ 移着層の久が， $\mathrm{TD}$ シリーズには $\mathrm{Cr}$ 移着層と拡散層の 両者が，また，Dシリーズには $\mathrm{Cr}$ 拡散層のみが被処理面に 形成されているかを確認した。

Fig. 4 に，被処理材の縦断面の SEM 観察および EDX に
よる元素分析を行った結果を，また Fig. 5 に，表面を XRD により分析した結果を示す。まず Fig. 4(a)のTシリーズで は，表面近傍で $\mathrm{Cr} の$ みが検出される領域が存在することが わかる。これは， $\mathrm{Cr}$ 移着層の久が形成されたことを示すも のであり，XRDの分析結果(Fig. 5(a))を考慮すると，移着 した Cr は単体もしくは酸化物として存在していると結論づ けられる。なお，酸化物は，チャンバー内の微量な酸素の存 在により，形成されたものと考えられる。 また，Fig. 4(b) の $\mathrm{TD} シ リ ー ス ゙ て ゙ は ， \mathrm{Cr}$ 移着層の直下で $\mathrm{Fe}$ と $\mathrm{Cr}$ が混在し ていることがわかる，これは， $\mathrm{Cr}$ 移着層の直下に $\mathrm{Cr}$ 拡散層 が形成されたことを示している。これらに対して Dシリー ズでは，最表面まで $\mathrm{Fe}$ と $\mathrm{Cr}$ が混在した $\mathrm{Cr}$ 拡散層のみが形 成されていることがわかる(Fig. 4(c))。これは，XRDの分 析結果 (Fig. 5(c)) で移着物に起因する回折ピークが検出さ れない事実と対応している.

以上の分析結果は，狙いぞ抢り， T シリーズには $\mathrm{Cr}$ 移着

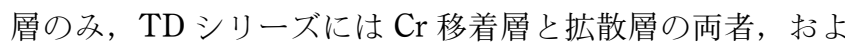

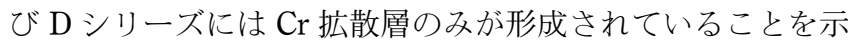
すものである。

\section{2 窒化層形成挙動に及ぼす AIH-FPP の影響}

Fig. 6 に，窒化を施した試験片 $(\mathrm{T}+\mathrm{N}, \mathrm{TD}+\mathrm{N}, \mathrm{D}+\mathrm{N}$ シ リーズ)の縦断面に抏いてビッカース硬さ分布を測定した結 果を示す，なお，同図には比較のために窒化のみを施した試 験片 $(\mathrm{N}$ シリーズ)の結果も示している。同図より， $\mathrm{N}$ シ

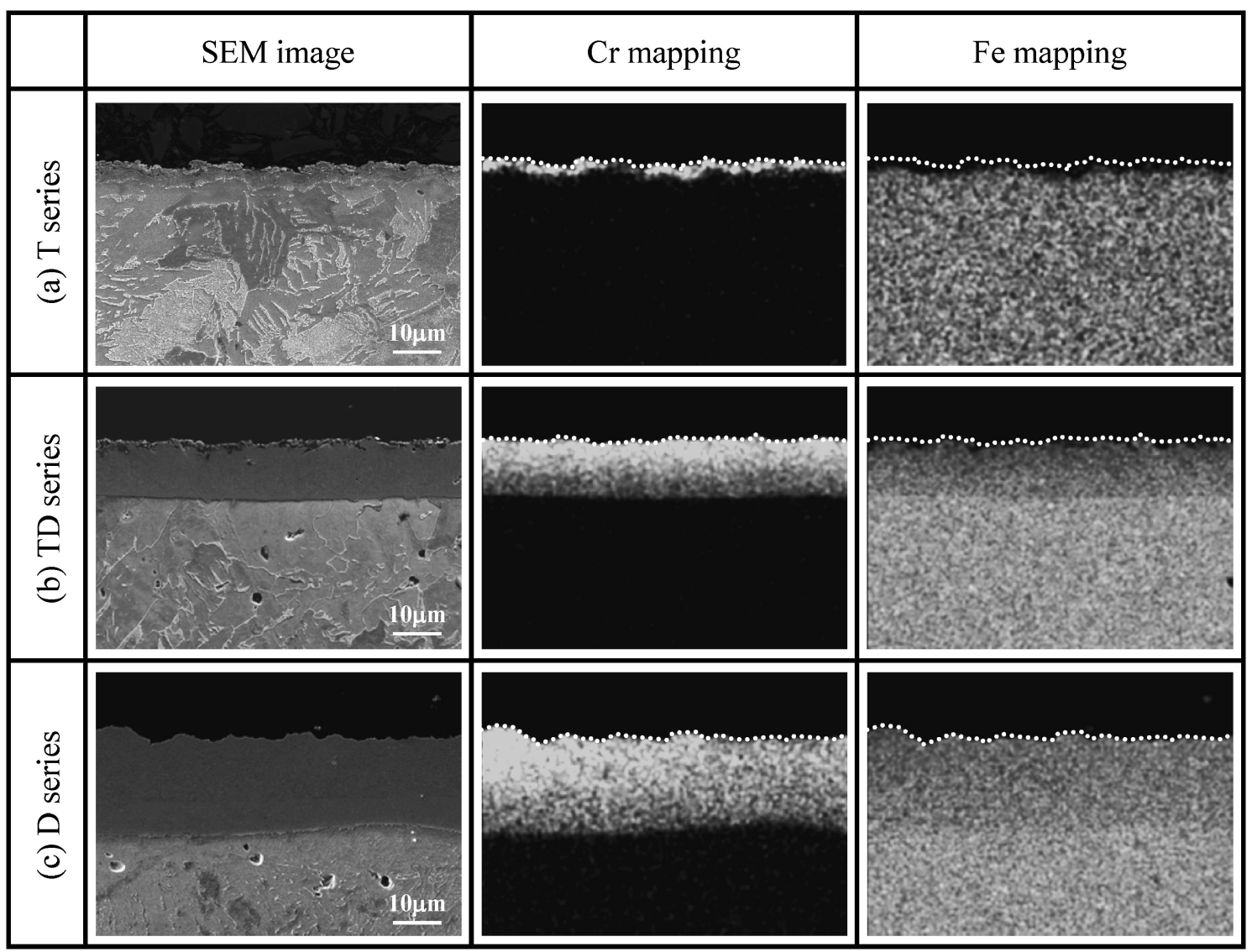

Fig. 4 SEM image and EDX mapping observed at longitudinal sections of before nitriding series. 


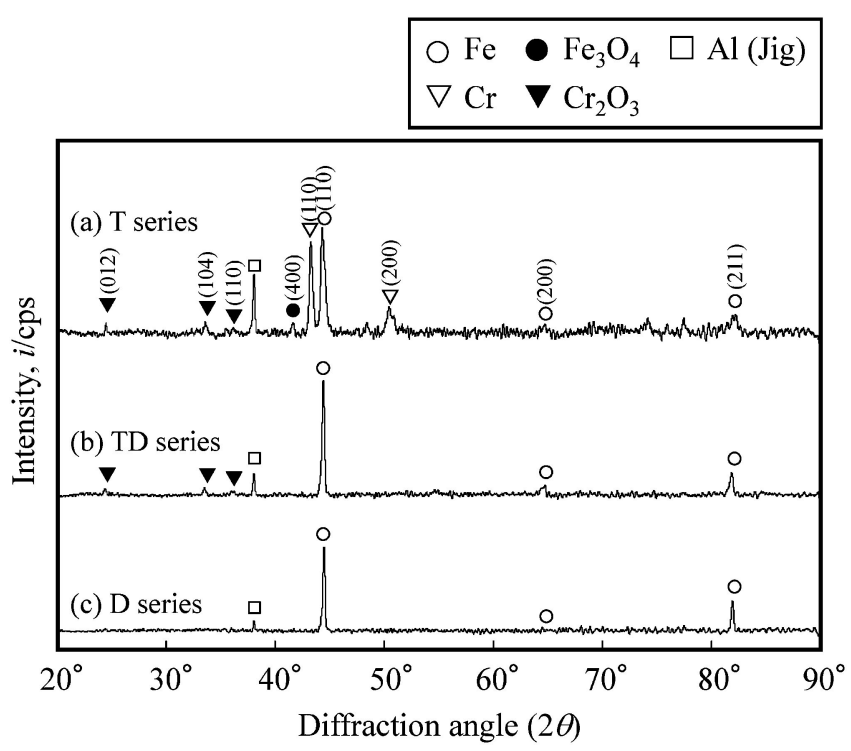

Fig. 5 X-ray diffraction pattern of before nitriding series.

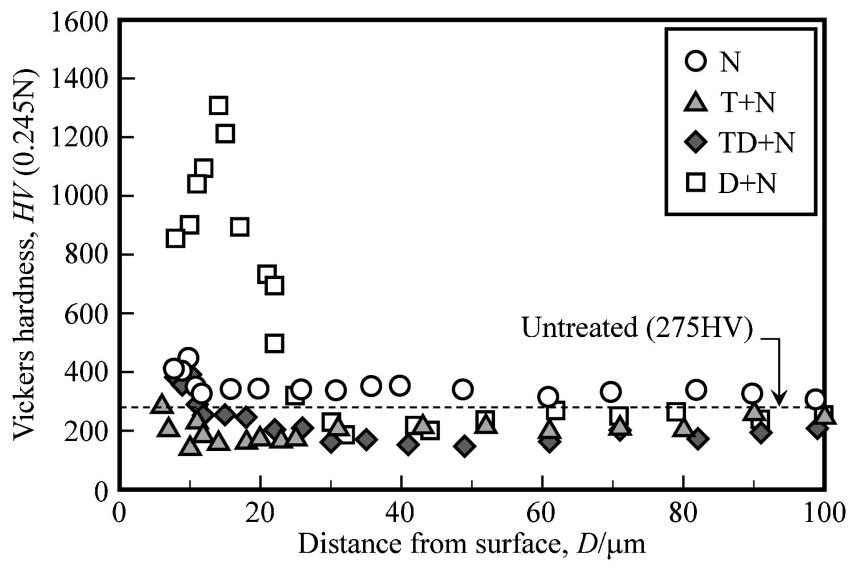

Fig. 6 Distributions of Vickers hardness of after nitriding series.

リーズの硬さと比較して， $\mathrm{T}+\mathrm{N}$ 打よび $\mathrm{TD}+\mathrm{N}$ シリーズは 低硬さであること，一方 D + N シリーズは深さ $15 \mu \mathrm{m}$ で $1300 \mathrm{HV}$ 程度の高い硬さを示して抢り，大幅に硬さが上昇 していることがわかる.このことは，一段目の AIH-FPPに より形成された表面改質層の状態に依存して, 窒化処理後の 硬さの分布形態が変化することを示すものである.

この点について検討を加えるためにまず，窒化前後の各試 験片の断面組織を観察した．Fig. 7 に，その結果を示す(図 中の破線は試験片の最表面を表す)。な抢，これらの写真は 試験片の綐断面を研磨した後，3\%ナイタールを用いて現出 させた組織を光学顕微鏡により観察したものである.

窒化前のシリーズと比較すると, $\mathrm{TD}+\mathrm{N}$ シリーズでは大 きな組織変化は認められない。これに対して, $\mathrm{T}+\mathrm{N}$ シリー ズでは移着層の一部が黒色に変化していること，および D $+\mathrm{N}$ シリーズでは拡散層がすべて黒色に変化していること がわかる。このように断面組織に色の変化が生じたことか ら，窒化により $\mathrm{Cr}$ の窒化物や $\mathrm{Fe}$ もしくは $\mathrm{Cr}$ の酸化物，炭 化物などの化合物が形成されたことが考えられる。な抢，す
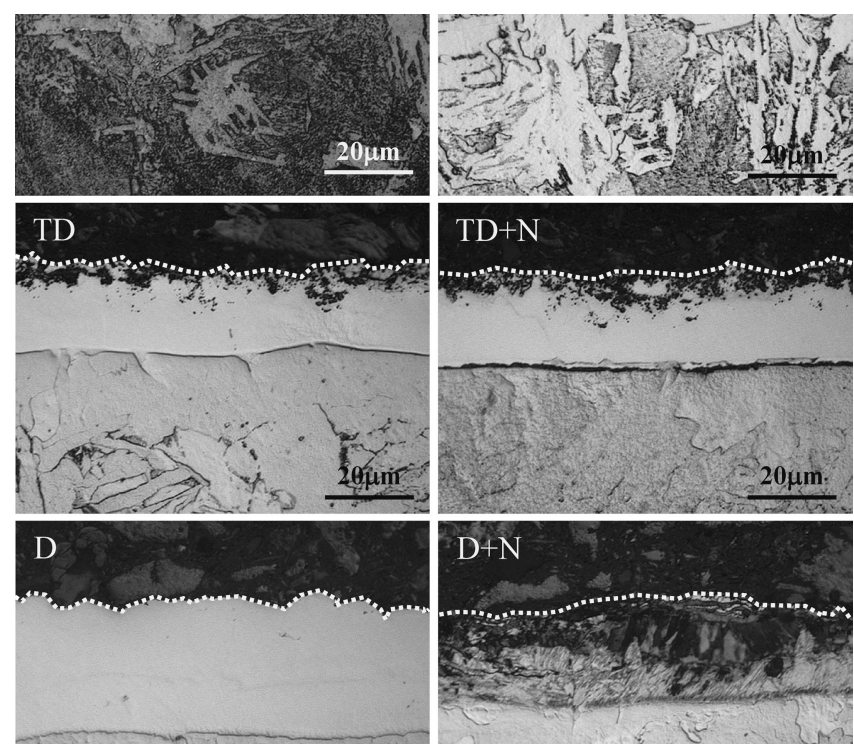

Fig. 7 Optical micrographs at longitudinal sections etched with $3 \%$ nital.

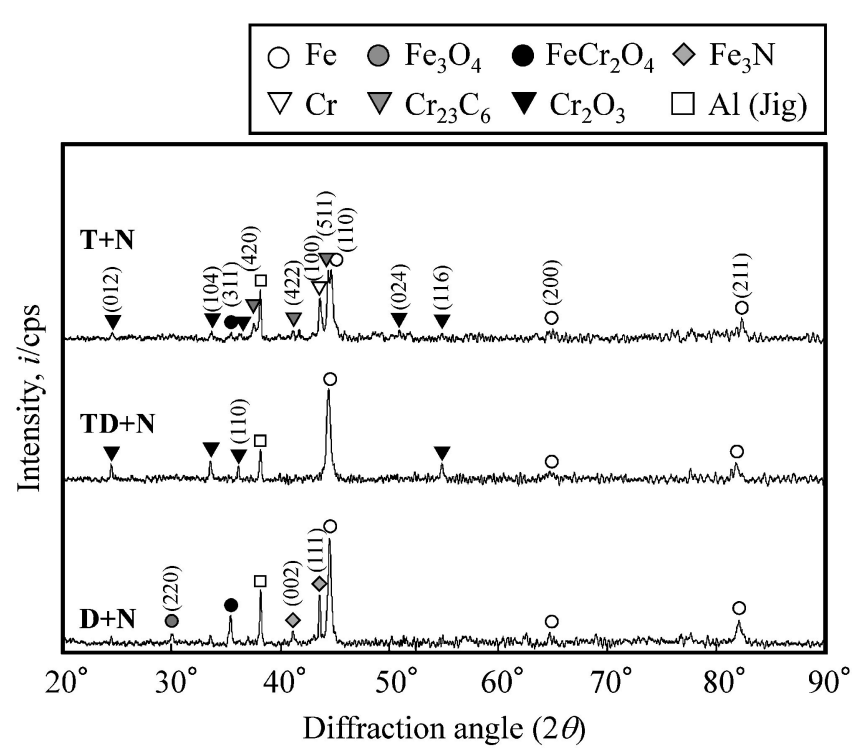

Fig. 8 X-ray diffraction pattern of after nitriding series.

ベてのシリーズで脱炭が認められるが，これはチャンバー内 の微量な酸素の存在により生じたものと考えられる.そのた め，AIH-FPP を施したシリーズの基材内部の硬さは未処理 材よりも低い值を示したものと考えられる(Fig. 6).

そこで次に，XRDによる分析を行い，表面の化合物同定 を行った．Fig. 8 に，その結果を示す．表面に $\mathrm{Cr}$ 粒子の移 着層を有する $\mathrm{T}+\mathrm{N}$ シリーズでは $\mathrm{Cr}$ 酸化物 $\left(\mathrm{Cr}_{2} \mathrm{O}_{3}(\boldsymbol{\nabla})\right)$, $\mathrm{Cr}$ 炭化物 $\left(\mathrm{Cr}_{23} \mathrm{C}_{6}(\nabla)\right)$ 抢よび $\mathrm{Fe}$ と $\mathrm{Cr}$ の複酸化物 $\left(\mathrm{FeCr}_{2} \mathrm{O}_{4}\right.$ ○) )の回折ピークが, $\mathrm{TD}+\mathrm{N}$ シリーズでは $\mathrm{Cr}$ 酸化物 $\left(\mathrm{Cr}_{2} \mathrm{O}_{3}(\boldsymbol{\nabla})\right)$ の回折ピークが主として検出されて抢り, 両シ リーズとも窒化物の回折ピークは検出されていないことがわ かる。これは，一段目の AIH-FPPにより移着した $\mathrm{Cr}$ の酸 化物が二段目の窒化工程での窒素の拡散を阻害したためと考 えられる。そのため, $\mathrm{T}+\mathrm{N}$ 抢よび $\mathrm{TD}+\mathrm{N}$ シリーズは $\mathrm{N} シ$ リーズと比較して低い硬さを示したものと考えられる. 
それに対して表面に $\mathrm{Cr}$ 拡散層のみを有する試験片に対し て窒化を施した D+Nシリーズでは， $\mathrm{Fe}$ 酸化物 $\left(\mathrm{Fe}_{3} \mathrm{O}_{4}(\mathrm{O})\right.$ ，

$\left.\mathrm{FeCr}_{2} \mathrm{O}_{4}(\boldsymbol{O})\right)$ に加え, $\mathrm{Fe}$ 窒化物 $\left(\mathrm{Fe}_{3} \mathrm{~N}(\diamond)\right)$ の回折ピークが 検出されている。これは，表面に窒化層が形成されたことを 示すものであるが， Fe 窒化物のみでは $1300 \mathrm{HV}$ 程度の硬さ を有する窒化層は得られないことが知られている。したがっ

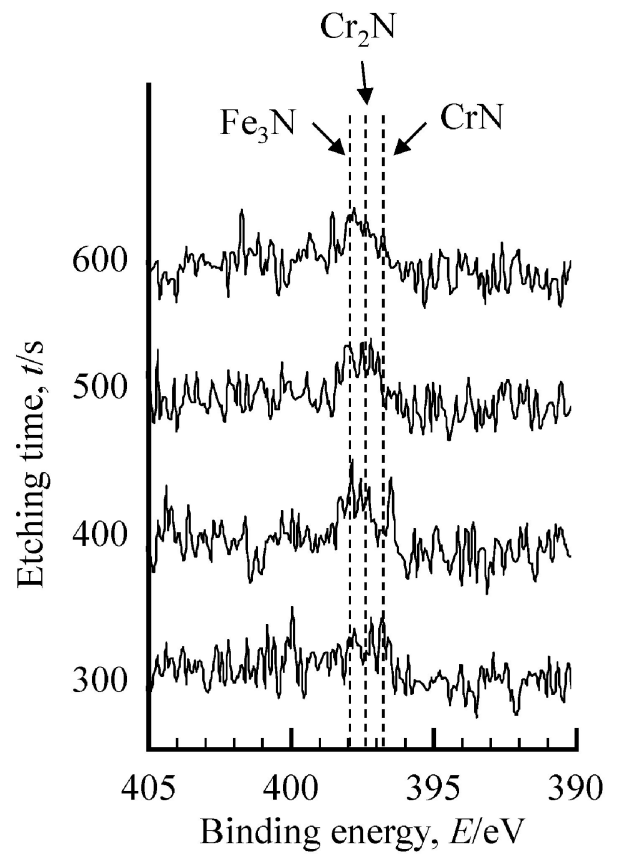

Fig. 9 XPS results for analysis of N $1 \mathrm{~s}(\mathrm{D}+\mathrm{N}$ series $)$.
て，D+Nシリーズの窒化層には，XRDでは検出されにく

いCr 窒化物も形成されているものと推測される.

この点を確かめるため，XPS を用いて結合エネルギーの 分析を行った. その際, 試験片表面からエッチングを施し, 深さ方向に分析を行った. Fig. 9 に, 分析結果の代表例を示 す。同図より，表面近傍に颃いて $\mathrm{Cr}$ 窒化物 $\left(\mathrm{CrN}, \mathrm{Cr}_{2} \mathrm{~N}\right)$ が 形成されていることがわかる。このような $\mathrm{Cr}$ 窒化物を含む 窒化層が形成されたため, $\mathrm{D}+\mathrm{N}$ シリーズの窒化層は高硬さ となったものと考えられる。

\section{3 窒化層硬さに及ぼす $\mathrm{Cr}$ 濃度の影響}

前節のビッカース硬さ分布の測定結果 (Fig. 6) から, 前処 理で $\mathrm{Cr}$ 拡散層のみを形成させた $\mathrm{D}+\mathrm{N}$ シリーズは, 未処理

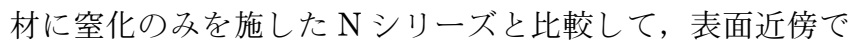

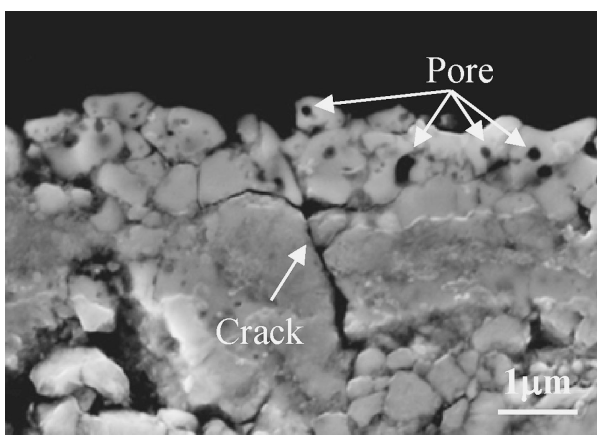

Fig. 10 SEM images at the longitudinal section $(\mathrm{D}+\mathrm{N}$ series).

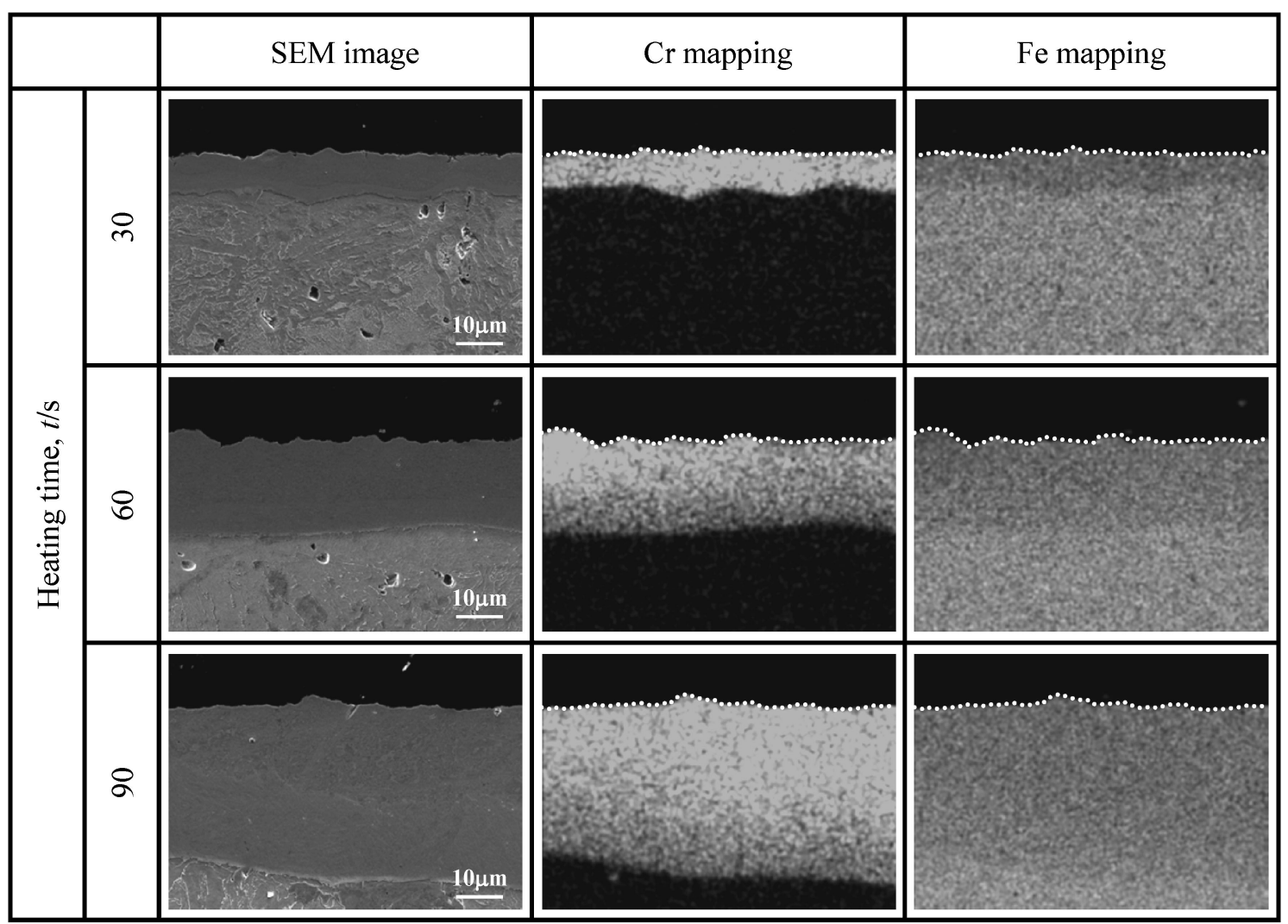

Fig. 11 SEM image and EDX mapping observed at longitudinal sections of before nitriding series (Peening pressure: $0.5 \mathrm{MPa}$, Particle supply rate: $0.2 \mathrm{~g} / \mathrm{s}$, Peening time: $30 \mathrm{~s}$ ). 
は大幅に硬さが上昇することが明らかとなった，しかしなが ら, 深さ $15 \mu \mathrm{m}$ の硬さ $(1300 \mathrm{HV})$ と比較して, 表面近傍で は明らかに硬さが低下している。この要因を検討するため, $\mathrm{D}+\mathrm{N}$ シリーズの試験片縦断面の表面近傍を SEM により詳 細に観察した。その結果(Fig. 10), 表面近傍では多数の空 隙が形成され，それに起因して微小なき裂も発生しているこ とが明らかとなった.このような空隙は, 窒化工程で被処理 材に拡散した $\mathrm{N}$ が $\mathrm{N}_{2}$ に再結合して形成11)されるものと考え

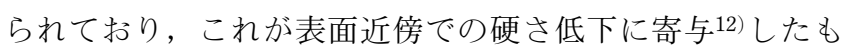
のと考えられる.

$\operatorname{Diaz} ら^{13)}$ は, 鋼中の $\mathrm{Cr}$ の濃度が高いほど, 窒素の溶解量 が増加することを, また Hosmani ら ${ }^{11)}$ は, 窒化の際に鋼中 への窒素溶解量が多いほど, 空隙が形成されやすくなること を報告している。したがって，鋼中の Cr 濃度が高いほど， 空隙が形成されやすくなるものと考えられる.

そこで本研究では，Dシリーズ（加熱保持時間 $60 \mathrm{~s}$ ) と比 較して $\mathrm{Cr}$ 拡散層の $\mathrm{Cr}$ 濃度を増加および減少させた試験片 に対して窒化を施し，その影響を検討することとした．そこ でまず，粒子投射後の加熱保持時間を $30 \mathrm{~s}$ 抢よび $90 \mathrm{~s}$ とし た試験片を準備し, 形成された表面改質層の分析を行った.

Fig. 11 に，種々の加熱保持時間で AIH-FPP のみを施し た試験片の縦断面の SEM 観察抢よび EDX による元素分析 結果を示す. 同図より, すべての試験片で $\mathrm{Cr}$ 移着層は存在 せず，表面まで $\mathrm{Cr}$ と $\mathrm{Fe}$ が混在した $\mathrm{Cr}$ 拡散層が形成されて いること, また加熱保持時間が長いほどその厚さが増加して いることがわかる. また, 各試験片の表面の $\mathrm{Cr}$ 濃度を測定 した結果 (Fig. 12), 加熱保持時間が長いほぼ, Cr 濃度が低 下していることがわかり, 目的とした表面改質層が形成され ていることが明らかとなった。これは, 被処理面に拡散した Cr が，粒子投射後の加熱保持により内部へと拡散したため と考えられる. なお, 以下加熱保持時間を $30 \mathrm{~s}$ として処理 した試験片を DH シリーズ， $90 \mathrm{~s}$ として処理した試験片を DL シリーズと呼ぶ.

これらの試験片 (DH, DL シリーズ)に対してガス窒化を施 し $(\mathrm{DH}+\mathrm{N}, \mathrm{DL}+\mathrm{N}$ シリーズ $)$ その表面近傍を SEM により 観察した結果を Fig. 13 に示す。同図より，表面 $\mathrm{Cr}$ 濃度が 比較的高い $\mathrm{DH}+\mathrm{N}$ シリーズの表面には, Fig. 10 に示した $\mathrm{D}+\mathrm{N}$ シリーズと同様に, 窒化により空隙とき裂が多数形成 されていることがわかる，それに対して表面 $\mathrm{Cr}$ 濃度を低下

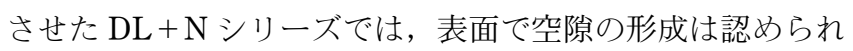
るもののき裂は確認できず(Fig. 13(b)), 空隙が形成されて いない領域も多く認められた (Fig. 13(c)).

そこで次に, 試験片縦断面に掞いてビッカース硬さ分布を 測定し, 表面近傍における硬さ低下が抑制されたかを確かめ た. Fig. 14 に，その結果を示す. 同図より, 空隙とき裂が 存在する $\mathrm{DH}+\mathrm{N}$ および $\mathrm{D}+\mathrm{N}$ シリーズでは, 表面近傍で硬 さが低下しているのに対し, 空隙の形成が抑制された DL+ N シリーズでは, 表面近傍での硬さ低下が抑制され, 深さ $40 \mu \mathrm{m}$ までの領域で $1400 \mathrm{HV}$ 程度の硬さを示していること がわかる. 以上の結果は, $\mathrm{Cr}$ 拡散層の表面 $\mathrm{Cr}$ 濃度を制御す ることにより, 窒化に伴う空隙の形成を抑制し, 高硬さの表 面を実現できる可能性を示すものである.

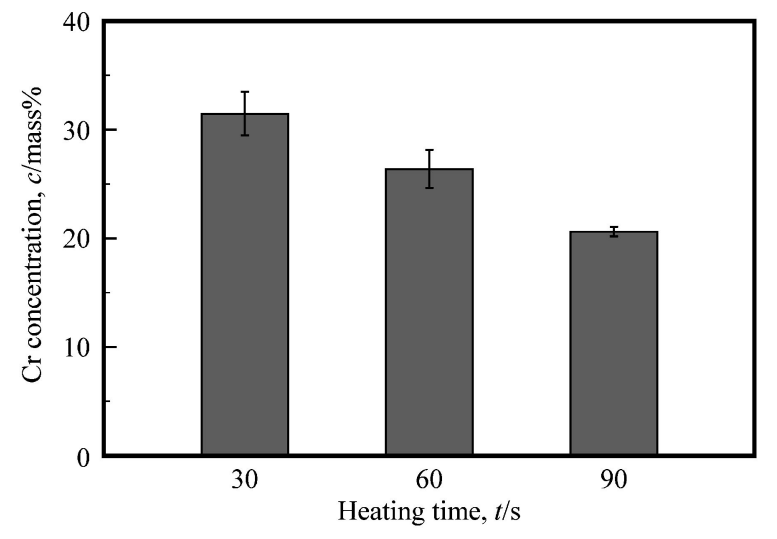

Fig. $12 \mathrm{Cr}$ concentration at the surface of before nitriding series (Peening pressure: $0.5 \mathrm{MPa}$, Particle supply rate: $0.2 \mathrm{~g}$ / $\mathrm{s}$, Peening time: $30 \mathrm{~s}$, mean \pm S.D., $n=10$ ).

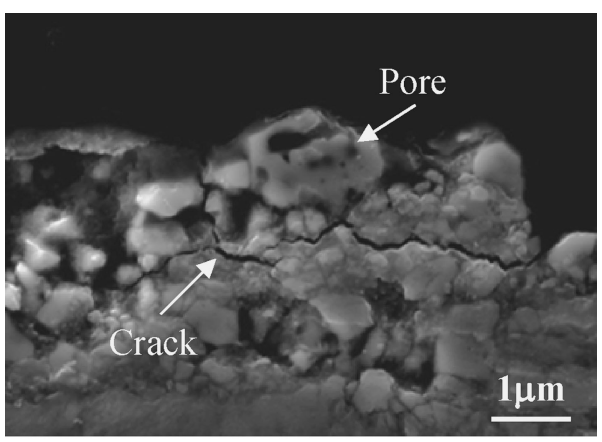

(a) $\mathrm{DH}+\mathrm{N}$ series

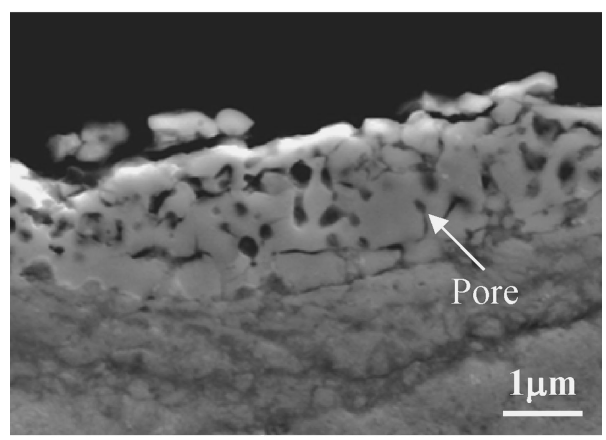

(b) $\mathrm{DL}+\mathrm{N}$ series

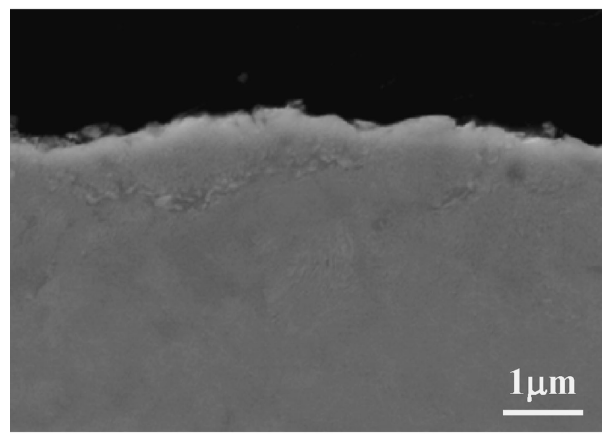

(c) DL+N series

Fig. 13 SEM images at the longitudinal sections of after nitriding series(Peening pressure: 0.5 MPa, Particle supply rate: $0.2 \mathrm{~g} / \mathrm{s}$, Peening time: $30 \mathrm{~s}$, Heating time: $30,90 \mathrm{~s}$ ). 


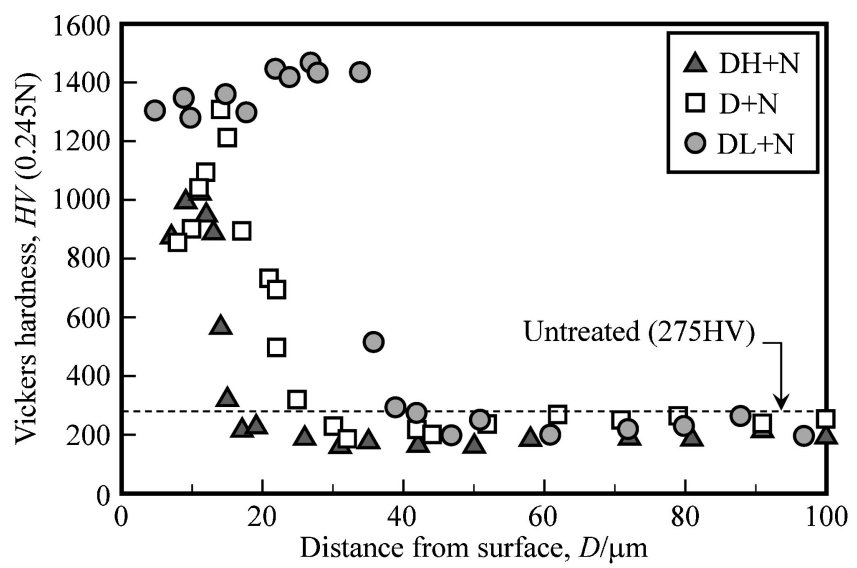

Fig. 14 Distributions of Vickers hardness of after nitridng series (Peening pressure: $0.5 \mathrm{MPa}$, Particle supply rate: $0.2 \mathrm{~g} /$ s, Peening time: $30 \mathrm{~s}$, Heating time: $30,60,90 \mathrm{~s}$ ).

\section{4. 結 論}

本研究では，炭素鋼表面の高硬さ化を目的とした新しい表 面改質プロセスとして，AIH-FPP/ガス窒化複合表面処理を 提案し, その効果について微視組織変化に着目して検討·考 察を加えた。以下に，得られた結論を示す。

(1) 炭素鋼に対して, 前処理として AIH-FPP を施し $\mathrm{Cr}$ の拡散層を形成させた後にガス窒化を施すと，その表面には $\mathrm{Cr}$ 窒化物を含む窒化層が形成され，その結果， $1400 \mathrm{HV}$ 程 度の高硬さとなる。

(2) 前処理後の表面に， Cr 粒子やその酸化物で構成され る移着層が形成されている場合には, ガス窒化では高硬さの $\mathrm{Cr}$ 窒化物を形成させることはできない。これは， $\mathrm{Cr}$ 酸化物 の存在が窒化工程における窒素の拡散を阻害するためである.

(3) 前処理後の表面に， Cr 拡散層のみが形成されている 場合には，その $\mathrm{Cr}$ 濃度に依存して表面近傍の硬さ分布は変
化する，すなわち, 表面 $\mathrm{Cr}$ 濃度が高い場合には, 表面近傍 に空隙や微小なき裂が多数形成され，その結果硬さは低下す る。それに対して，表面 $\mathrm{Cr}$ 濃度が低くなるような条件で前 処理を施した場合, 硬さ低下は抑制され厚い硬化層を形成す ることができる。

以上の結果は, $\mathrm{Cr}$ 粒子を用いて適切な条件で $\mathrm{AIH}-\mathrm{FPP}$ を鋼に施すことにより，その後の窒化工程で形成される改質 層が，きわめて高硬さとなることを示唆するものである。

本研究の一部は，大澤科学技術振興財団の補助の下で行わ れた。記して感謝の意を表す。

文献

1) D. Y. Chang, S. Y. Lee and S.-G. Kang: Surf. Coat. Technol. 116-119 (1999) 391-397.

2) S. Taktak, S. Ulker and I. Gunes: Surf. Coat. Technol. 202 (2008) 3367-3377.

3) V. H. Baggio-Scheid, G. de Vasconcelos, M. A. S. Oliveira and B. C. Ferreira: Surf. Coat. Technol. 163-164 (2003) 313-317.

4) H. Cao, C. P. Luo, J. Liu and G. Zou: Surf. Coat. Technol. 201 (2007) 7970-7977.

5) A. Basu, J. Dutta Majumdar, S. Ghosh Chowdhury, P. K. Ajikumar, P. Shankar, A. K. Tyagi, B. Raj and I. Manna: Surf. Coat. Technol. 201 (2007) 6985-6992.

6) J. Y. Eom, V. S. Rao and H. S. Kwon: J. Mater. Res. 18 (2003) 861-867.

7) A. Dasgupta, P. Kuppusami, M. Vijayalakshmi and V. S. Raghunathan: J. Mater. Sci. 42 (2007) 8447-8453.

8) T. Ito, S. Kikuchi, Y. Kameyama, J. Komotori, K. Fukazawa, Y. Misaka and K. Kawasaki: J. Japan Inst. Metals 74 (2010) 533539.

9) T. Fukuoka, S. Kikuchi, J. Komotori, K. Fukazawa, Y. Misaka and K. Kawasaki: J. Japan Inst. Metals 75 (2011) 372-378.

10) T. Fukuoka, Y. Ujiie, J. Komotori, K. Fukazawa, Y. Misaka and K. Kawasaki: Proc. Eng. 10 (2011) 1503-1508.

11) S. S. Hosmani, R. E. Schacherl and E. J. Mittemeijer: Harterei Tech. Mitt. 63 (2008) 139-146.

12) M. Pellizzari, A. Molinari and G. Straffelini: Mater. Sci. Eng. A 352 (2003) 186-194.

13) N. E. Vives Diaz, R. E. Schacherl, L. F. Zagonel and E. J. Mittemeijer: Acta Mater. 56 (2008) 1196-1208. 